Jurnal Geocelebes Vol. 5 No. 2, Oktober 2021, 144 - 158

\title{
IDENTIFIKASI PERCEPATAN TANAH MAKSIMUM DAN INTENSITAS GEMPA BUMI DI SUMATRA BARAT MENGGUNAKAN METODE GUTENBERG-RICHTER
}

\author{
Erna Yustika Hutasoit ${ }^{1}$, Ira Kusuma Dewi ${ }^{1 *}$, Faizar Farid $^{2}$ \\ ${ }^{1}$ Program Studi Teknik Geofisika, Fakultas Sains dan Teknologi, Universitas Jambi, Jl. Jambi - Muara Bulian \\ Km. 15, Jambi, 36361, Indonesia. \\ ${ }^{2}$ Program Studi Kimia, Fakultas Sains dan Teknologi, Universitas Jambi, Jl. Jambi - Muara Bulian Km. 15, \\ Jambi, 36361, Indonesia. \\ *Corresponding author. Email: ierha.kd@gmail.com
}

Manuscript received: 9 June 2021; Received in revised form: 27 September 2021; Accepted: 13 October 2021

\begin{abstract}
Abstrak
Sumatra Barat memiliki tingkat kegempaan cukup tinggi karena berada pada zona Megathrust, Sesar Mentawai, dan Sesar Sumatra. Tingginya tingkat kegempaan ini mempengaruhi nilai percepatan tanah di Sumatra Barat yang merupakan parameter penting dalam perencanaan bangunan tahan gempa. Metode Gutenberg-Richter merupakan salah satu metode empiris untuk menghitung nilai percepatan tanah maksimum (PGA) dan intensitas gempa bumi berdasarkan magnitudo gempa. Data penelitian ialah data katalog gempa bumi dari BMKG dan USGS dengan periode 01 Januari 2005 hingga 15 September 2020 dengan magnitudo gempa $\mathrm{Mb} \geq 3$ dan kedalaman $\leq 70 \mathrm{~km}$. Berdasarkan data BMKG diperoleh gempa bumi sebanyak 1136 kejadian dan menunjukkan nilai PGA di Sumatra Barat sekitar $0,16-1,44 \mathrm{~m} / \mathrm{s}^{2}$ dengan intensitas V-VIII MMI serta episenter menyebar di zona akresi, zona Sesar Sumatra dan zona Sesar Mentawai. Sedangkan dari USGS diperoleh gempa bumi sebanyak 1140 kejadian dan menunjukkan nilai $0,28-1,35 \mathrm{~m} / \mathrm{s}^{2}$ dengan intensitas VI-VIII MMI serta episenter yang menyebar di zona Sesar Mentawai. Berdasarkan analisis data baik dari BMKG maupun USGS diperoleh bahwa Kabupaten Kepulauan Mentawai adalah wilayah yang memiliki tingkat risiko gempa bumi paling tinggi dan berpotensi tsunami dengan nilai percepatan tanah maksimum sekitar 1,29-1,44 m/s dengan intensitas VIII MMI.
\end{abstract}

Kata Kunci: Gutenberg-Richter; intensitas gempa; percepatan tanah maksimum; Sumatra Barat.

\begin{abstract}
West Sumatra has a fairly high level of seismicity because it is located in the Megathrust, Mentawai Fault, and Sumatra Fault zones. This high level of seismicity affects the value of ground acceleration in West Sumatra which is an important parameter in the design of earthquake-resistant buildings. The Gutenberg-Richter method is an empirical method to calculate the maximum ground acceleration (PGA) and earthquake intensity based on the earthquake magnitude. The research data is earthquake catalog data from BMKG and USGS for the period January 1, 2005 to September 15, 2020 with an earthquake magnitude of Mb 3 and a depth of $70 \mathrm{~km}$. Based on BMKG data, 1136 earthquakes were obtained and showed PGA values in West Sumatra were around $0.16-1.44 \mathrm{~m} / \mathrm{s}^{2}$ with an intensity of V-VIII MMI and the epicenters spread in the accretion zone, Sumatra Fault zone and Mentawai Fault zone. Meanwhile, from USGS, 1140 earthquakes were obtained and showed a value of $0.28-1.35 \mathrm{~m} / \mathrm{s}^{2}$ with an intensity of VI-VIII MMI and an epicenter that spreads in the Mentawai Fault zone. Based on data analysis from both BMKG and USGS, it was found that the Mentawai Islands Regency is an area
\end{abstract}


that has the highest level of earthquake risk and has the potential for a tsunami with a maximum ground acceleration value of around $1.29-1.44 \mathrm{~m} / \mathrm{s}^{2}$ with an intensity of VIII MMI.

Keywords: Gutenberg-Richter; earthquake intensity; peak ground acceleration; West Sumatra

\section{Pendahuluan}

Sumatra Barat merupakan salah satu wilayah di Indonesia yang memiliki tingkat kegempaan cukup tinggi karena Sumatra Barat berada di pertemuan Lempeng IndoAustralia yang menunjam ke bawah Lempeng Eurasia yang membentuk jalur gempa bumi. Sumatra barat berada pada zona Megathrust, Sesar Mentawai, dan Sesar Sumatra (Douglas, 2001). Dalam catatan sejarah gempa bumi dahsyat yang pernah terjadi di Sumatra Barat yaitu pada 30 September 2009 dengan kekuatan Mw 7,5 dan intensitas VII MMI. Gempa ini menyebabkan kerusakan parah di beberapa wilayah Sumatra Barat dan menewaskan banyak orang (BMKG, 2021).

Tingginya aktivitas kegempaan mempengaruhi nilai percepatan tanah di wilayah Sumatra Barat. Percepatan tanah maksimum (PGA) adalah nilai percepatan tanah terbesar pada permukaan tanah yang pernah terjadi di suatu wilayah akibat gempa bumi. Oleh sebab itu, sangat dibutuhkan perhitungan PGA yang diakibatkan oleh gempa bumi untuk perencanaan bangunan tahan gempa karena menggambarkan kekuatan gempa bumi yang pernah terjadi, salah satunya dengan menggunakan metode Gutenberg-Richter (Syahputra, 2007).

Penelitian ini bertujuan untuk mengetahui nilai PGA dan intensitas gempa di Sumatra Barat menggunakan metode GutenbergRichter, mengetahui hubungan PGA dengan intensitas, mengetahui perbedaan data BMKG dengan USGS dan mengidentifikasikan tingkat risiko gempa bumi di wilayah Sumatra Barat. Berdasarkan lokasi yang rawan dengan gempa bumi, Sumatra Barat berpotensi dapat mengalami gempa bumi dengan magnitudo yang tinggi dan intensitas sekitar
VI-VIII MMI atau setara dengan 0,50 - 0,75 $\mathrm{m} / \mathrm{s}^{2}$ dalam tabel hubungan nilai percepatan tanah dan intensitas menurut Calvi dkk. (2006) pada Tabel (1) di bawah.

Tabel 1. Tingkat risiko gempa berdasarkan nilai percepatan tanah dan intensitas (Calvi dkk., 2006)

\begin{tabular}{|c|c|c|c|}
\hline No & $\begin{array}{l}\text { Tingkat } \\
\text { Risiko }\end{array}$ & $\begin{array}{l}\text { Percepatan } \\
\left(\mathrm{m} / \mathrm{s}^{2}\right)\end{array}$ & $\begin{array}{c}\text { Intensitas } \\
\text { (MMI) }\end{array}$ \\
\hline 1 & $\begin{array}{l}\text { Risiko } \\
\text { sangat kecil }\end{array}$ & $<0,25$ & $<\mathrm{VI}$ \\
\hline 2 & Risiko kecil & $0,25-0,50$ & VI-VII \\
\hline 3 & $\begin{array}{l}\text { Risiko } \\
\text { sedang satu }\end{array}$ & $0,50-0,75$ & VII-VIII \\
\hline 4 & $\begin{array}{l}\text { Risiko } \\
\text { sedang dua }\end{array}$ & $0,75-1,00$ & VII-VIII \\
\hline 5 & $\begin{array}{l}\text { Risiko } \\
\text { sedang tiga }\end{array}$ & $1,00-1,25$ & VII-VIII \\
\hline 6 & $\begin{array}{l}\text { Risiko besar } \\
\text { satu }\end{array}$ & $1,25-1,50$ & VIII-IX \\
\hline 7 & $\begin{array}{l}\text { Risiko besar } \\
\text { dua }\end{array}$ & $1,50-2,00$ & VIII-IX \\
\hline 8 & $\begin{array}{l}\text { Risiko besar } \\
\text { tiga }\end{array}$ & $2,00-3,00$ & VIII-IX \\
\hline 9 & $\begin{array}{l}\text { Risiko } \\
\text { sangat besar } \\
\text { satu }\end{array}$ & $3,00-6,00$ & IX-X \\
\hline 10 & $\begin{array}{l}\text { Risiko } \\
\text { sangat besar } \\
\text { dua }\end{array}$ & $>6,00$ & $>X$ \\
\hline
\end{tabular}

\section{Geologi Regional Sumatra Barat}

Menurut Koesoemadinata dan Matasak (1981), secara regional Sumatra Barat merupakan bagian dari empat lembar geologi yaitu Lembar Painan, Lembar Lubuksikaping, Lembar Solok, dan Lembar Padang. Geologi regional Sumatra Barat ditunjukkan pada Gambar 1.

Sumatra Barat terbagi dalam empat segmen sesar aktif. Segmen Sumpur terletak di Daerah Rao, Lubuk Sikaping Kabupaten Pasaman yang memiliki panjang patahan \pm $35 \mathrm{~km}$ dengan kecepatan pergerakan 14 $\mathrm{mm} / \mathrm{tahun}$. Segmen Sianok terletak memanjang dari sisi Timur Danau Singkarak dengan kecepatan pergeseran 14 
$\mathrm{m} /$ tahun. Segmen Sumani memiliki panjang $\pm 90 \mathrm{~km}$ dengan kecepatan pergeseran 14 $\mathrm{mm} /$ tahun. Segmen Suliti berada di Danau
Diatas dan Danau Dibawah dengan panjang segmen $\pm 90 \mathrm{~km}$ dan kecepatan pergerakan $6,5 \mathrm{~mm} / \operatorname{tahun}$ (Sieh dan Natawidjaja, 2000).

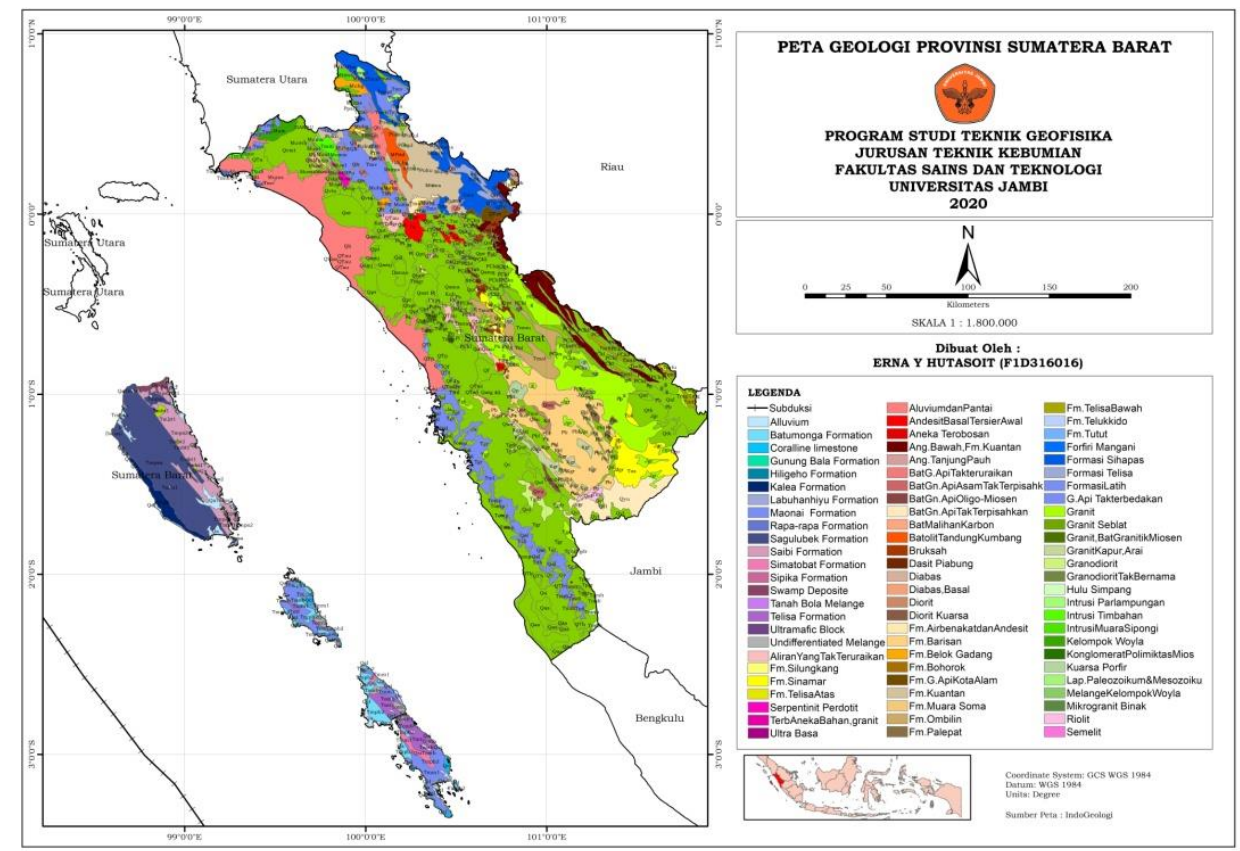

Gambar 1. Peta Geologi Sumatra Barat (Dimodifikasi dari Badan Informasi Geospasial, 2017).

\section{Gempa Bumi}

Gempa bumi adalah rangkaian gelombang getaran yang disebabkan adanya pelepasan energi regangan elastis batuan. Menurut Teori Elastic Rebound yang dinyatakan oleh Seismolog Amerika, Reid, (Bullen, 1965; Kawashumi, 1951) menyatakan bahwa gempa bumi merupakan gejala alam yang disebabkan oleh pelepasan energi regangan elastis batuan yang disebabkan adanya deformasi batuan yang terjadi pada lapisan litosfer.

\section{Metode Penelitian}

Pada penelitian ini dilakukan perhitungan percepatan tanah maksimum dan intensitas gempa bumi dengan metode GutenbergRichter di wilayah Sumatra Barat dengan periode gempa bumi yang terjadi dari 01 Januari 2005 hingga 15 September 2020 dengan magnitudo $\mathrm{Mb} \geq 3$ dan kedalaman $\leq$ $70 \mathrm{~km}$. Data katalog gempa bumi yang digunakan dalam pengolahan yaitu waktu terjadinya gempa, latitude, longitude, magnitudo, dan kedalaman yang diunduh dari situs resmi BMKG (www.bmkg.go.id) dan USGS (www.earthquake.usgs.gov).

$\begin{array}{lrr}\text { Metode } & \text { Gutenberg-Richter } & \text { merupakan } \\ \text { metode } & \text { yang bersifat } & \text { universal }\end{array}$ (menyeluruh) dan dapat digunakan untuk seluruh wilayah. Selain itu, metode Gutenberg-Richter paling tepat untuk menghitung nilai PGA dan intensitas gempa bumi berdasarkan nilai magnitudo (Scordilis, 2006).

Penelitian dimulai dengan perhitungan episenter pada Pers. (1) dan hiposenter pada Pers. (2).

$\operatorname{Cos} \Delta=\operatorname{Sin} \varphi_{1} \operatorname{Sin} \varphi_{2}+\operatorname{Cos} \varphi_{1} \operatorname{Cos} \varphi_{2} \operatorname{Cos}$ $\left(\lambda_{1}-\lambda_{2}\right)$

dengan: $\Delta$ : jarak episenter

$\varphi_{1}$ : lintang posisi episenter

$\varphi_{2}$ : lintang stasiun pengamat

$\lambda_{1}$ : bujur episenter

$\lambda_{2}$ : bujur stasiun pengamatan

$$
R=\sqrt{\Delta^{2}+h^{2}}
$$


dengan: $\Delta$ : jarak episenter $(\mathrm{km})$

$\mathrm{h}$ : kedalaman $(\mathrm{km})$

Nilai hiposenter digunakan untuk menghitung nilai percepatan tanah maksimum atau Peak Ground Acceleration (PGA) yang merupakan nilai terbesar percepatan tanah pada suatu tempat akibat getaran gempa bumi dalam periode waktu tertentu yang dipengaruhi oleh magnitudo, kedalaman, jarak episenter, dan kondisi tanah (Lubis dkk., 2007). Perhitungan nilai PGA menggunakan Persamaan GutenbergRichter pada Pers. (3) berikut.

$$
\log \alpha=\frac{I}{3}-0,5
$$

dengan: I: intensitas (MMI)

$$
\alpha \text { : percepatan tanah (gal) }
$$

Selain itu, dilakukan perhitungan nilai intensitas yang merupakan skala kekuatan gempa bumi berdasarkan hasil pengamatan efek gempa bumi terhadap manusia, struktur bangunan, dan lingkungan pada tempat tertentu yang dinyatakan dengan skala MMI (Modified Mercalli Intensity). Besarnya intensitas bergantung pada magnitudo, jarak dari sumber gempa (episenter), kondisi geologi, dan struktur bangunannya. Intensitas terkuat terjadi di wilayah episenter (Kawashumi, 1951).

Perhitungan nilai episenter menggunakan Persamaan Gutenberg-Richter pada Pers. (4) berikut.

$$
\mathrm{I}=1,5(\mathrm{M}-0,5)
$$

Dengan: I: intensitas (MMI)

M: magnitudo gempa bumi

Hubungan PGA dan intensitas gempa dinyatakan dengan Pers. (5) oleh Gutenberg-Richter berikut.

$$
\log \alpha=0,333 \text { IMM }-0,5
$$

dengan: $\alpha$ : percepatan maksimum (gal)

I: intensitas (MMI)

Hubungan intensitas pada suatu wilayah terhadap jarak dinyatakan pada Pers. (6) oleh Subardjo dan Harjadi (1993) yang ditentukan berdasarkan gempa Flores 12 Desember 1992.

$$
\mathrm{I}_{0}=\mathrm{I} \exp ^{-0,0021 \mathrm{R}}
$$

dengan: I: Intensitas (MMI)

$\mathrm{I}_{0}$ : Intensitas pada jarak episenter

R: Jarak episenter $(\mathrm{km})$

exp: Bilangan logaritma $=2,71828$

Hubungan intensitas dan PGA dinyatakan dalam grafik dengan pendekatan empiris menggunakan metode Gutenberg-Richter pada Pers. (5). Interpretasi hasil terhadap tingkat risiko gempa bumi di Sumatra Barat berdasarkan Tabel 1.

\section{Hasil dan Pembahasan}

Data gempa bumi yang diunduh dari BMKG maupun USGS memiliki format yang berbeda. BMKG hanya menampilkan longitude, latitude, waktu, kedalaman dan magnitudo (BMKG, 2021). Sedangkan USGS menampilkan waktu, longitude, latitude, kedalaman, magnitudo, nst (jumlah stasiun seismik yang digunakan untuk menentukan lokasi gempa), rms (kesesuaian waktu datang), place (wilayah terdekat dengan gempa), type (jenis peristiwa seismik), depthError (ketidakpastian kedalaman), magNst (jumlah stasiun untuk menghitung magnitudo), dan location source (sumber jaringan awal yang menentukan lokasi gempa) (USGS, 2021).

Data gempa bumi dari BMKG mencatat 1136 kejadian sedangkan USGS sebanyak 1140 kejadian. Seismisitas memuat persebaran gempa bumi berupa titik-titik gempa di suatu wilayah yang menunjukkan tingkat kerentanan terhadap gempa bumi. Peta seismisitas dari data BMKG ditampilkan pada Gambar 2 yang menunjukkan bahwa persebaran episenter terjadi hampir di setiap wilayah Sumatra Barat. Magnitudo gempa mulai dari M3 hingga M7 yang ditunjukkan oleh titik-titik gempa dengan warna yang berbeda agar lebih mudah mengetahui klasifikasi gempa 
bumi berdasarkan magnitudo. Gempa bumi dengan magnitudo M 3,0 - 3,9 (warna hijau tosca) sebanyak 518 gempa, M 4,0 - 4,9 (warna hijau) 209 gempa, M 5,0 - 5,9 (warna kuning) 367 gempa, M 6,0 - 6,9 (warna jingga) 37 gempa, dan M 7,0 - 7,9 (warna merah) 5 gempa.

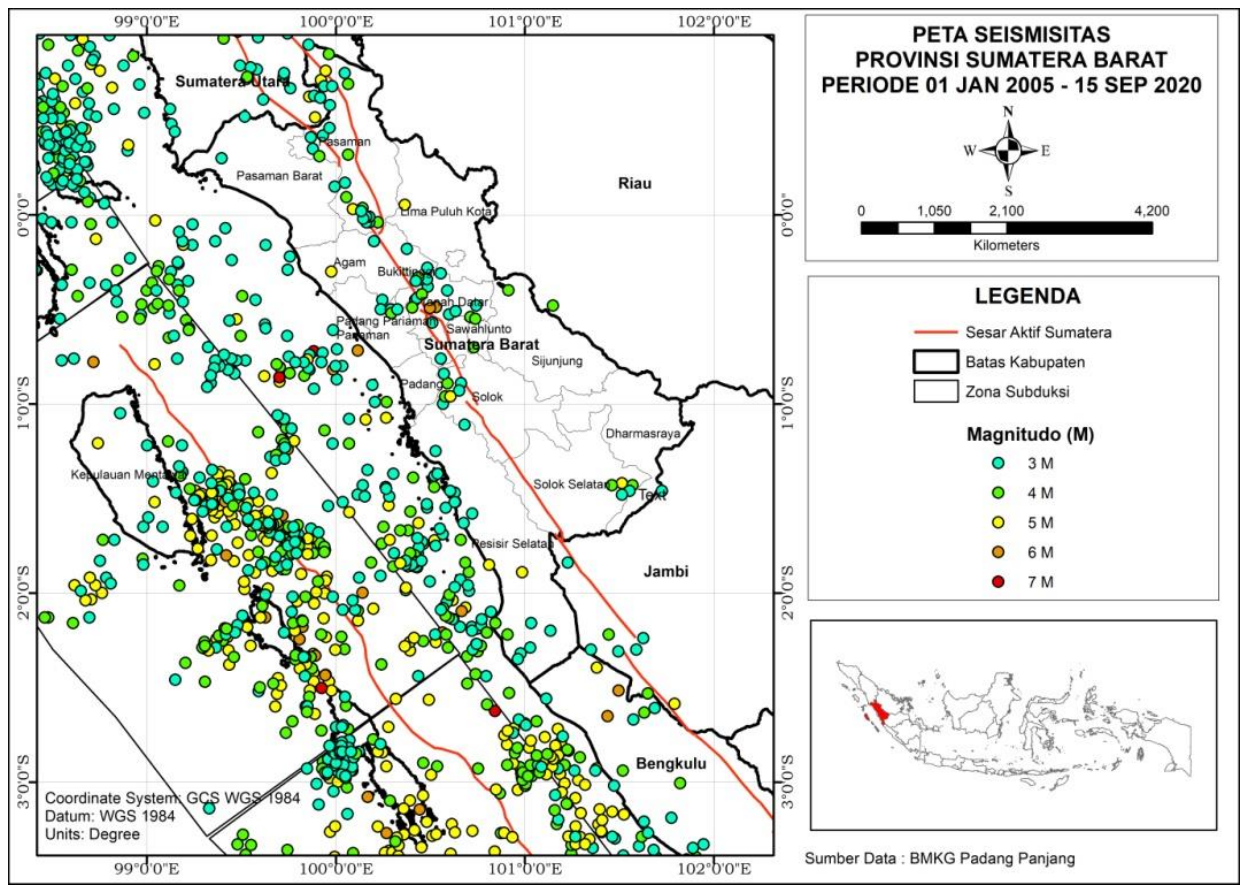

Gambar 2. Peta Seismisitas dari data BMKG

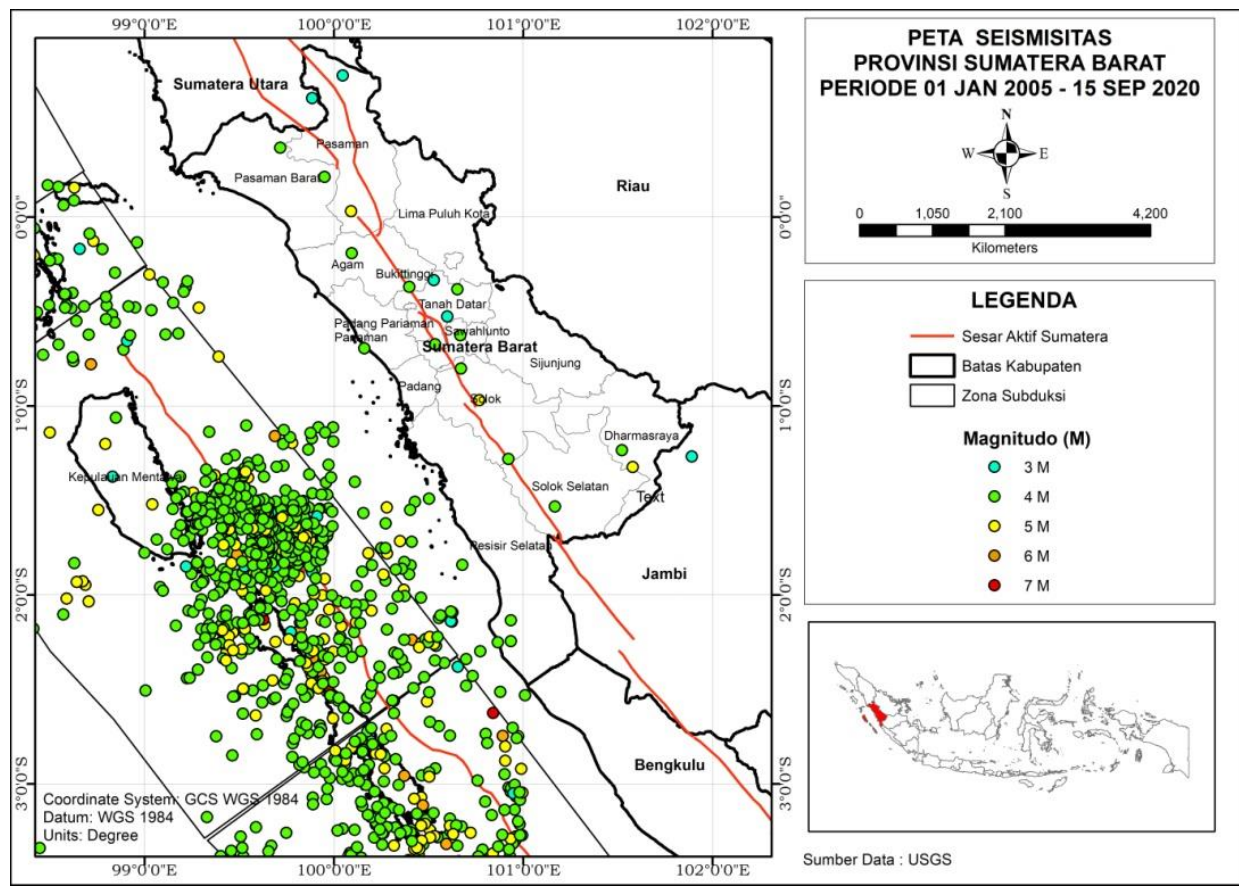

Gambar 3. Peta Seismisitas dari data USGS.

Peta seismisitas dari USGS ditampilkan pada Gambar 3 yang menunjukkan persebaran gempa bumi terjadi lebih banyak di perairan barat terutama di sekitar zona Sesar Mentawai. Gempa bumi dengan magnitudo M 3,0 - 3,9 (warna tosca) sebanyak 28 kejadian, M 4,0 - 4,9 (warna hijau) 918 kejadian, M 5,0 - 5,9 (warna kuning) 171 kejadian, M 6,0 - 6,9 (warna 
jingga) 19 kejadian, dan M 7,0 - 7,9 (warna merah) 4 kejadian.

Berdasarkan peta seismisitas baik dari BMKG maupun USGS dinyatakan bahwa di wilayah Sumatra Barat gempa bumi tersebar dan bersumber dari zona akresi (tinggian depan busur), zona Sesar Mentawai, dan zona Sesar Sumatra. Gempa bumi di zona akresi dikontrol oleh aktivitas sesar naik (thrusting) yang mengakibatkan pengangkatan (uplifting). Zona akresi paling rawan terhadap kegempaan karena pusat gempa berada di bawahnya dan menyebabkan gempa dangkal dengan kedalaman hingga $70 \mathrm{~km}$. Gempa bumi di zona Sesar Mentawai menyebabkan gempa bumi dengan kedalaman dangkal yang berada di cekungan depan busur. Sedangkan gempa bumi di zona Sesar Sumatra menyebabkan gempa bumi dangkal dan merusak. Walaupun sedikit, gempa bumi dengan magnitudo besar $(M>6)$ dapat terjadi di sepanjang jalur Sesar Sumatra (Lubis dkk., 2007; Neumann, 1954).

Gempa bumi dengan kedalaman dangkal dan terdapat di darat biasanya disebabkan oleh aktivitas sesar Sumatra yaitu yang termasuk dalam jenis gempa interplate. Gempa bumi dengan kedalaman dangkal dan berada di perairan biasanya disebabkan oleh aktivitas Sesar Mentawai yang terjadi karena stress (tekanan) pada lempeng tersubduksi dan bersifat pergerakan naik (thrust). Sedangkan gempa bumi dangkal hingga dalam biasanya terjadi di zona akresi (tinggian depan busur) yaitu gempa bumi dengan pergerakan naik akibat adanya strain (regangan) di dalam lempeng (Sieh dan Natawidjaja, 2000).

Berdasarkan data BMKG (Gambar 4), kedalaman gempa bumi di Sumatra Barat mulai dari $10 \mathrm{~km}$ hingga 69,70 km. Peta persebaran kedalaman gempa dibuat dengan warna yang berbeda untuk memudahkan dalam mengklasifikasikan gempa bumi yang terjadi. Gempa dengan kedalaman yang berbeda tersebar di wilayah Sumatra Barat, baik di zona sesar maupun zona dekat subduksi. Gempa dengan kedalaman $10 \mathrm{~km}$ hingga $30 \mathrm{~km}$ lebih banyak di zona Sesar Mentawai dan Sesar Sumatra. Sedangkan gempa dengan kedalaman $31 \mathrm{~km}$ hingga 70 $\mathrm{km}$ lebih banyak berada di wilayah perairan.

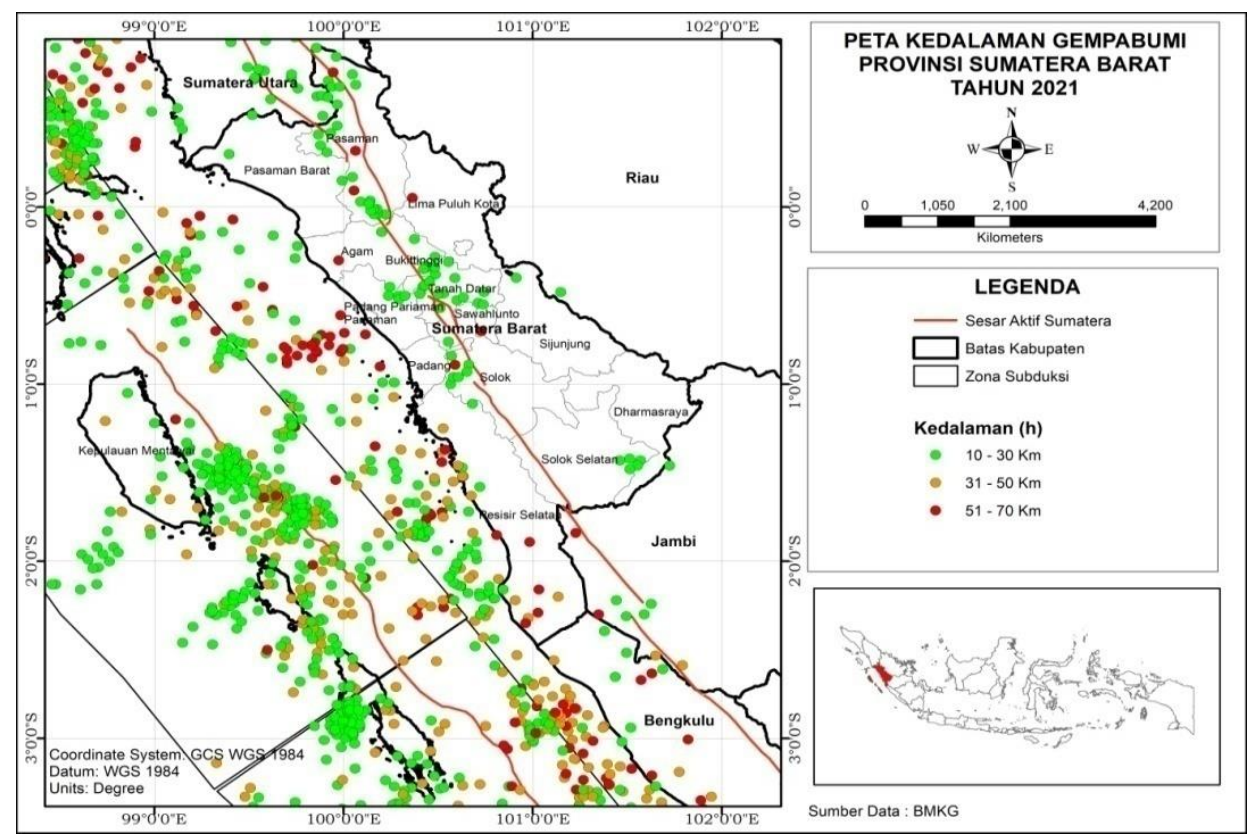

Gambar 4. Peta kedalaman dari data BMKG.

Berdasarkan data dari USGS (Gambar 5), gempa bumi yang terjadi memiliki kedalaman paling dangkal 12,86 $\mathrm{km}$ dan paling dalam $68,15 \mathrm{~km}$. Wilayah yang 
memiliki kedalaman $10-30 \mathrm{~km}$ berada di perairan barat dekat Mentawai dan ada juga di sekitar segmen Sumatra Barat. Wilayah dengan kedalaman $30-50 \mathrm{~km}$ dan $50-70$ km juga berada di perairan barat walaupun ada yang berada di wilayah daratan Sumatra Barat.

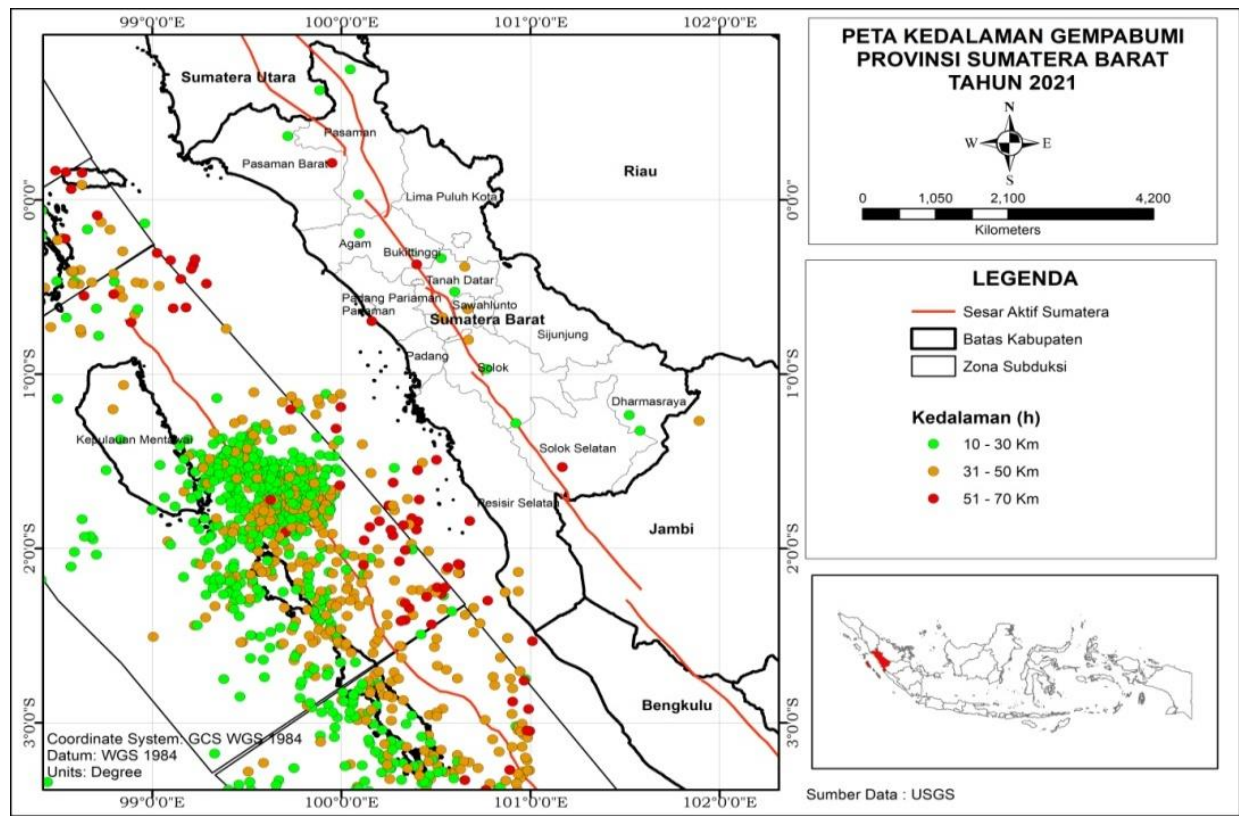

Gambar 5. Peta kedalaman dari data USGS

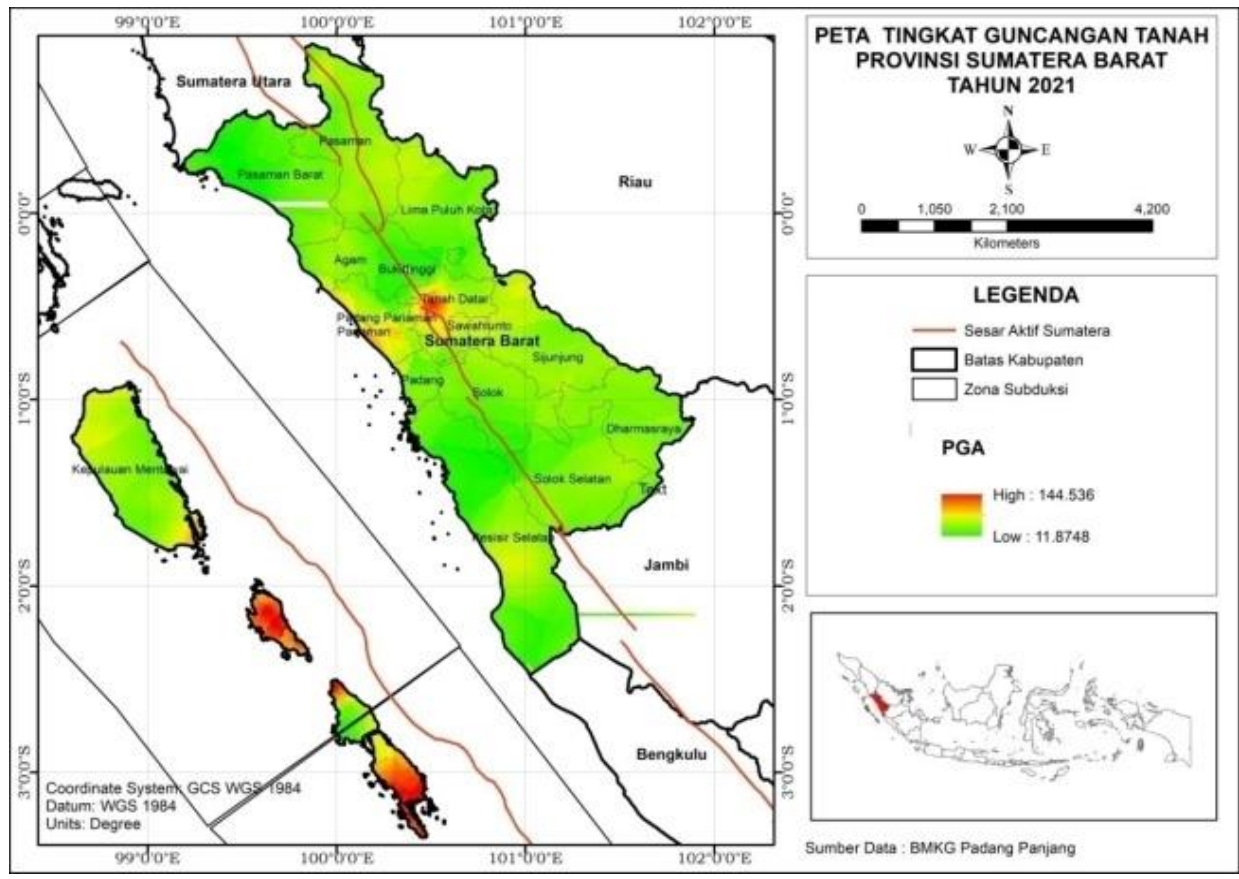

Gambar 6. Peta PGA dari data BMKG

Berdasarkan data dari BMKG dan USGS, gempa memiliki kedalaman yang dangkal yaitu $<70 \mathrm{~km}$. Menurut Sieh dan Natawidjaja (2000) ketebalan kerak di Pulau Sumatra 15 - $70 \mathrm{~km}$. Jadi gempa bumi di Sumatra Barat terjadi di kerak bumi karena memiliki kedalaman $<70 \mathrm{~km}$. Pada dasarnya gempa sering terjadi di kerak, hanya saja di lokasi (sumber) yang berbeda.

Gempa bumi akan mempengaruhi PGA di wilayah sekitar episenter. Berdasarkan data BMKG, nilai PGA di wilayah Sumatra Barat berkisar antara $0,12-0,144 \mathrm{~m} / \mathrm{s}^{2}$ yang 
ditunjukkan pada Gambar 6. Nilai PGA ditandai dengan interpolasi warna hijau hingga ke merah. Semakin merah wilayah yang ditunjukkan pada peta berarti semakin tinggi nilai PGA di wilayah tersebut. Gambar 6 menunjukkan bahwa PGA terbesar berada di wilayah Kepulauan Mentawai bagian tenggara dan Tanah Datar. Sedangkan di wilayah kabupaten lainnya memiliki nilai PGA yang kecil.

Tingginya nilai PGA di sekitar Kabupaten Tanah Datar ini disebabkan oleh gempa bumi yang terjadi di $14 \mathrm{~km}$ barat daya Tanah Datar pada Kamis, 11 September 2014 dengan magnitudo M 5,0 dan kedalaman 10 $\mathrm{km}$. Hal ini dikarenakan posisi sumber gempa yang dekat dengan wilayah tersebut dan terletak pada kedalaman yang dangkal. Wilayah Tanah Datar, Batu Sangkar dan Padang Panjang sebagian besar tersusun oleh endapan aluvium (lanau, pasir, dan kerikil) yang berumur Kuarter termasuk endapan rawa yang bersifat urai, lepas dan belum kompak sehingga rawan terhadap terjadinya gempa bumi. Berdasarkan posisi hiposenter dapat diperkirakan bahwa gempa bumi yang terjadi di Tanah Datar disebabkan oleh aktivitas Segmen Sianok (BMKG, 2021).

Hal ini sesuai dengan penelitian yang dilakukan oleh Marlisa, Pujiastuti, dan Billyanto (2016) yang menganalisis PGA di Sumatra Barat dengan metode Mc. Guire. Data penelitian yaitu kejadian gempa bumi 11 September 2014 yang berlokasi di $0,57^{\circ}$ LU dan $100,53^{\circ}$ BT tepatnya berada di Segmen Sianok dengan kedalaman gempa $10 \mathrm{~km}$ dan magnitudo $M \quad 5,0$. Hasil penelitian tersebut bahwa PGA tertinggi berada di sekitar wilayah Tanah Datar yaitu sekitar $0,28 \mathrm{~m} / \mathrm{s}^{2}$. Dampak gempa dirasakan sangat kuat atau intensitas VII - VIII MMI dengan kemampuan merusak kategori sedang. Nilai PGA terkecil berada di wilayah Pasaman, Pesisir Selatan, Solok Selatan, dan Dharmasraya.

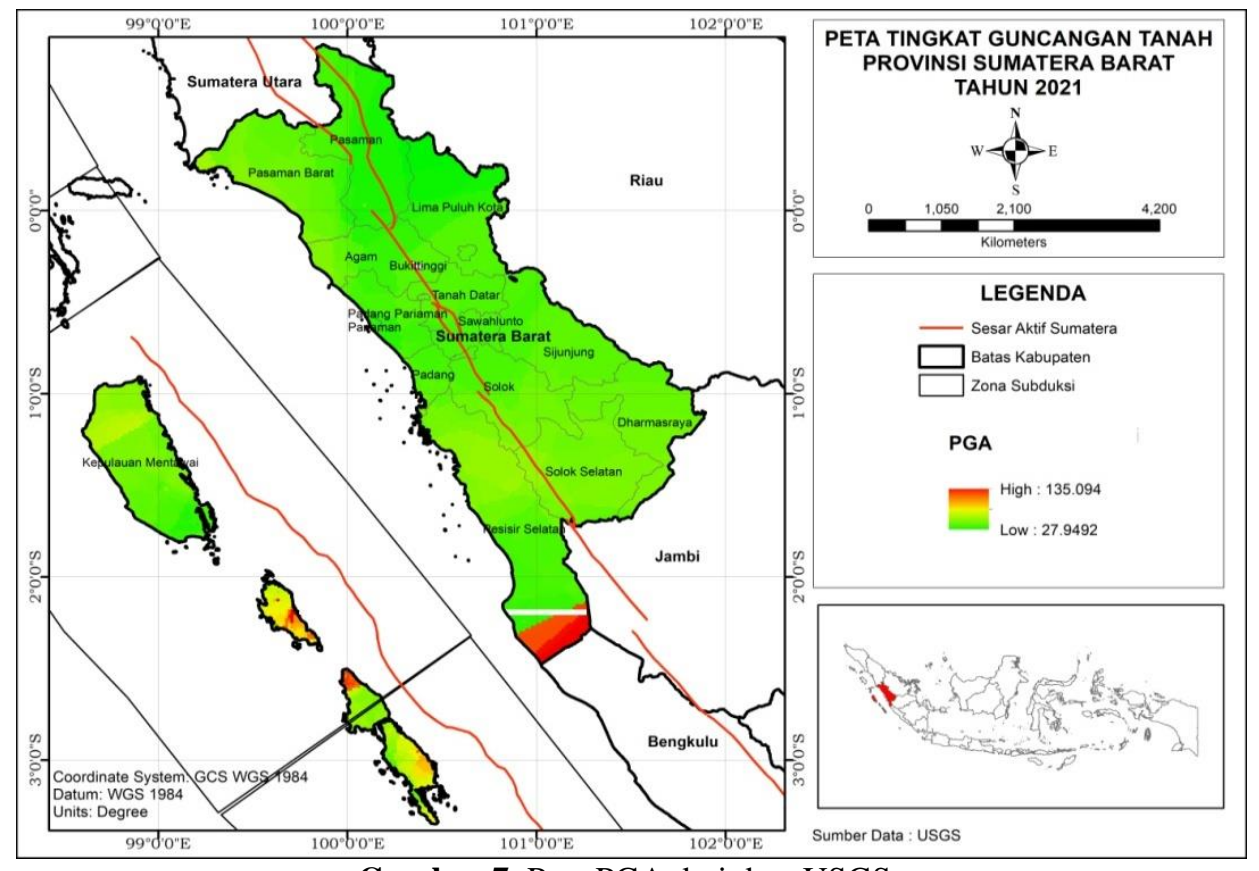

Gambar 7. Peta PGA dari data USGS.

Data dari USGS menunjukkan bahwa wilayah Sumatra Barat memiliki nilai PGA sekitar $0,28-1,35 \mathrm{~m} / \mathrm{s}^{2}$ yang ditunjukkan pada Gambar 7. Wilayah di Sumatra Barat dengan percepatan tanah yang besar berada di Kabupaten Pesisir Selatan bagian selatan dan Kabupaten Mentawai bagian tenggara. Sementara wilayah lainnya memiliki nilai PGA yang nilai kecil baik di sekitar sesar maupun di sepanjang pantai Sumatra Barat. Tingginya nilai PGA di wilayah Pesisir Selatan disebabkan oleh besarnya pengaruh 
gempa yang terjadi di $2,62^{\circ} \mathrm{LS}$ dan $100,84^{\circ}$ BT, pada 12 September 2007 dengan magnitudo M 7,9 dan kedalaman $35 \mathrm{~km}$. Wilayah ini berada dekat dengan Pantai Barat Sumatra yang sebagian besar tersusun dari endapan danau, dan aluvium berupa pasir, lanau, lempung, lumpur dan tuf yang berumur Kuarter. Guncangan gempa bumi akan terasa lebih kuat di wilayah yang disusun oleh endapan aluvium karena sifat batuan tersebut akan memperkuat efek guncangan gempa bumi (BMKG, 2021).

Berdasarkan peta PGA dari data BMKG dan USGS menunjukkan hasil yang berbeda. Pada peta seismisitas data BMKG ditunjukkan persebaran episenter yang merata hampir di setiap wilayah sedangkan
USGS menunjukkan persebaran episenter yang hampir seluruh kejadian berada di perairan Pantai Barat Sumatra Barat yaitu di sekitar Zona Sesar Mentawai

Intensitas gempa tertinggi berada pada wilayah yang dekat dengan episenter berdasarkan hasil pengamatan terhadap manusia, dan lingkungan pada suatu tempat (Bullen, 1965). Berdasarkan data BMKG, ditunjukkan bahwa wilayah Sumatra Barat memiliki intensitas mulai dari V hingga VIII MMI (Gambar 8). Wilayah yang memiliki intensitas paling tinggi yaitu di sekitar bagian tenggara Kepulauan Mentawai yaitu VIII MMI dan disusul dengan VII MMI di wilayah sekitar Kabupaten Sawahlunto dan Tanah Datar.

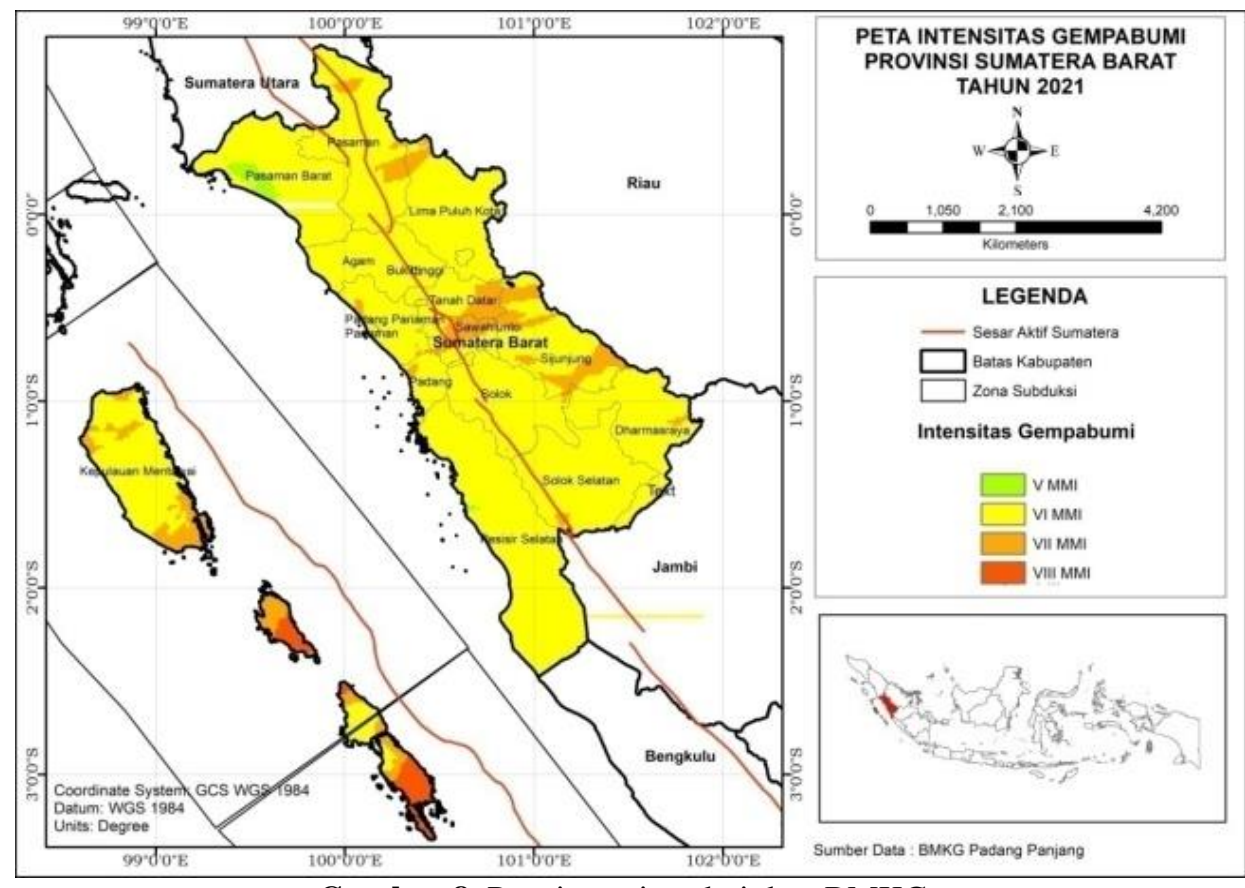

Gambar 8. Peta intensitas dari data BMKG.

Tingginya nilai intensitas di Kepulauan Mentawai dipengaruhi oleh gempa bumi pada 25 Februari 2008 dengan magnitudo $\mathrm{M}$ 7,2 dan kedalaman $33 \mathrm{~km}$. Intensitas gempa ini sekitar VII MMI dan mengakibatkan beberapa rumah mengalami kerusakan. Intensitas paling rendah berada di wilayah Kabupaten Pasaman Barat bagian barat dengan intensitas V MMI. Sementara wilayah kabupaten lainnya memiliki intensitas sekitar VI MMI. Interpolasi pada peta PGA dengan peta intensitas memiliki pola yang hampir sama yaitu nilai tertingginya berada di wilayah Kepulauan Mentawai dan Sawahlunto serta Tanah Datar. Wilayah dengan nilai PGA tinggi akan menunjukkan intensitas yang tinggi.

Data dari USGS menunjukkan bahwa Sumatra Barat memiliki intensitas mulai dari VI-VIII MMI. Pada Gambar 9, wilayah dengan intensitas tertinggi berada di bagian 
Tenggara Kepulauan Mentawai dengan intensitas VIII MMI. Wilayah dengan intensitas rendah berada di Kabupaten dan Kota Pariaman yaitu VI MMI. Sedangkan wilayah kabupaten lainnya Pasaman, Lima Puluh Kota bagian Utara, memiliki intensitas VII MMI.

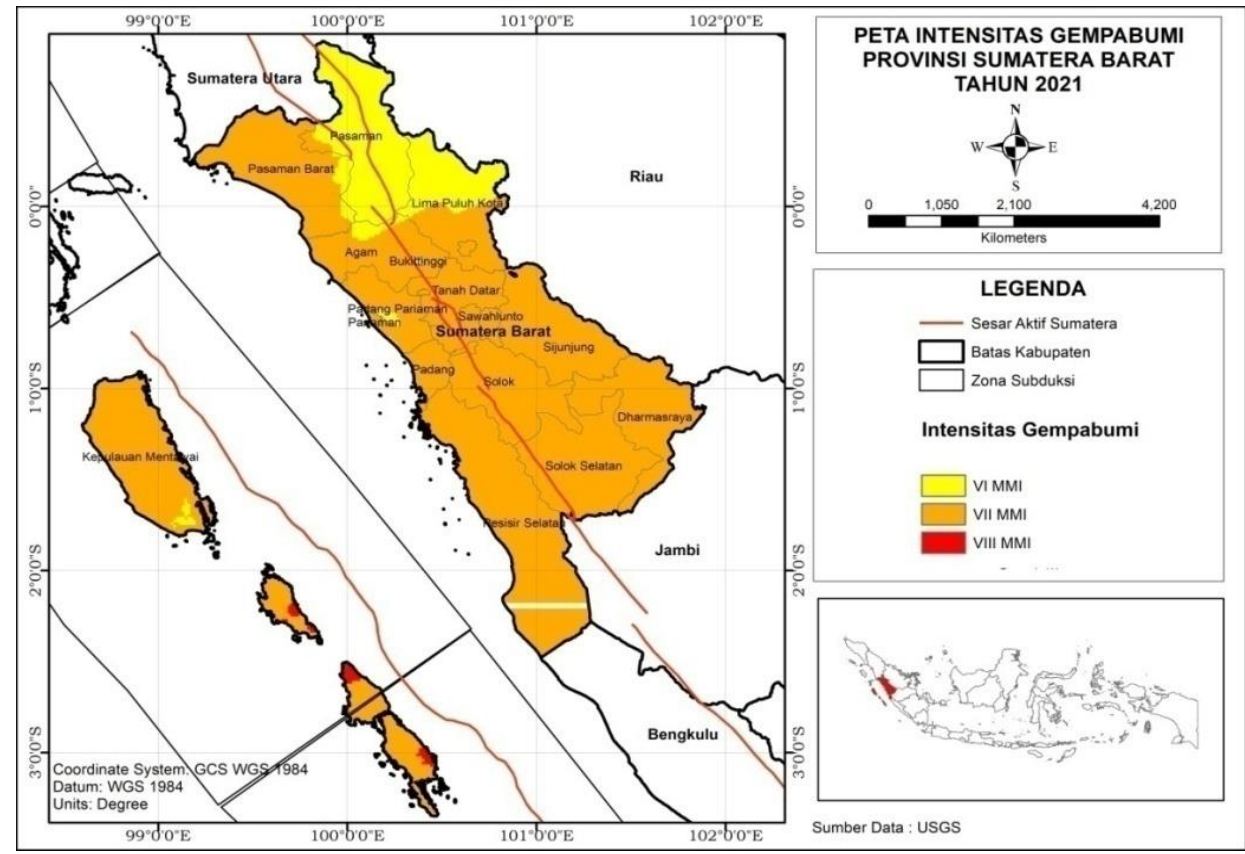

Gambar 9. Peta intensitas dari data USGS.

Tingginya nilai intensitas di wilayah Kabupaten Mentawai disebabkan pengaruh dari gempa bumi yang terjadi di lepas pantai Sumatra dekat dengan Kepulauan Mentawai sekitar $240 \mathrm{~km}$ sebelah barat Bengkulu pada 25 Oktober 2010 dengan magnitudo M 7,7 dan kedalaman 20,6 km. Gempa mengakibatkan kerusakan bangunan serta fasilitas pemerintahan dan banyak menelan korban jiwa yang juga menyebabkan tsunami. Gempa bumi ini terjadi di sedimen lunak (endapan dasar laut) yang tebal dan dekat dengan dasar laut di zona subduksi, sehingga energi gempa menggerakkan massa batuan yang lebih besar pada sedimen bawah air tersebut (USGS, 2021).

Berdasarkan perhitungan dan analisis data dari BMKG dan USGS diperoleh hasil yang berbeda yang dapat dilihat pada Tabel 2 .

Tabel 2. Perbedaan BMKG dan USGS.

\begin{tabular}{ccc}
\hline Faktor Pembeda & BMKG & USGS \\
\hline Format data & Sederhana & Kompleks \\
Persebaran episenter & Menyebar di seluruh wilayah & Zona Sesar Mentawai \\
Kedalaman hiposenter & $10-61,71 \mathrm{~km}$ & $12,86-57,98 \mathrm{~km}$ \\
PGA & $0,16-1,44 \mathrm{~m} / \mathrm{s}^{2}$ & $0,28-1,35 \mathrm{~m} / \mathrm{s}^{2}$ \\
Intensitas & V-VIII MMI & VI-VIII MMI \\
Wilayah PGA tinggi & Mentawai, Tanah Datar & Pesisir Selatan \\
Wilayah intensitas tinggi & Mentawai, Sawahlunto & Mentawai \\
\hline
\end{tabular}

Hal mendasar yang membedakan pada kedua sumber data tersebut adalah penentuan waktu tiba gelombang, distribusi stasiun dan jumlahnya, serta penggunaan model kecepatan yang digunakan. BMKG merekam data gempa bumi dari stasiun seismik yang lebih dekat dengan episenter dan kemudian diteruskan ke BMKG Pusat di Jakarta. Sedangkan USGS memperoleh data gempa bumi dari NEIC (National Earthquake Information Center) yang bertindak sebagai ANSS (National 
Operations Center of the Advanced National Seismic System) yaitu kerja sama antara NEIC dengan operator jaringan seismik di seluruh dunia yang melaporkan setiap kejadian kepada NEIC.

Gempa darat, dangkal, atau dekat dengan stasiun penentuan waktu tiba gelombang lebih rumit dibandingkan gempa jauh karena menunjukkan banyak jenis gelombang lain (selain gelombang P) yang bisa direkam jelas oleh stasiun lokal. Oleh karena itu, USGS lebih berfokus pada penentuan waktu tiba gelombang P karena jarak yang cukup jauh dari sumber gempa. Pada dasarnya, semakin banyak stasiun yang merekam gelombang gempa bumi maka semakin akurat datanya.
Selain itu, model kecepatan yang digunakan juga dapat berpengaruh pada data yang dihasilkan. BMKG menggunakan model kecepatan IASP91 yaitu model kecepatan satu dimensi yang dihasilkan International Association of Seismology and Physics of the Earth's Interior (IASPEI). Nilai kecepatan diperoleh berdasarkan ribuan data gelombang $\mathrm{P}$ dan $\mathrm{S}$ yang terekam oleh sensor. Asumsi medium pada model IASP91 adalah homogenitas medium yakni medium dianggap sama (Marlisa, Pujiastuti, dan Billyanto, 2016). Sedangkan USGS menggunakan model kecepatan AK135 merupakan model kecepatan yang dirancang untuk memberikan kesesuaian yang baik untuk berbagai fase seismik dan biasanya nilai kecepatannya didasarkan pada gelombang P (USGS, 2021).

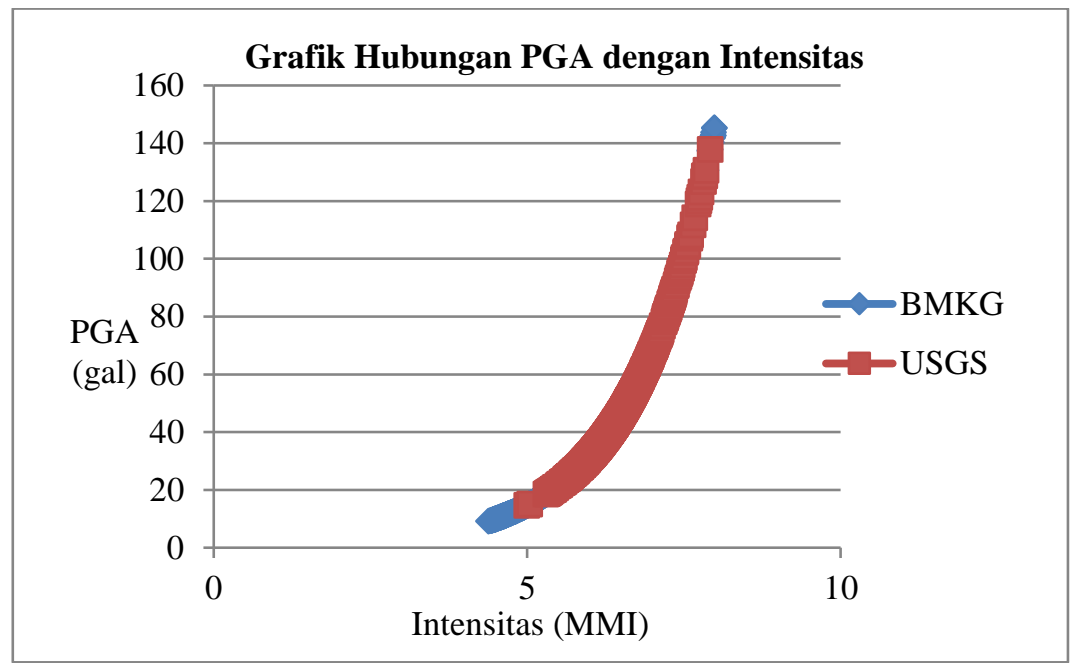

Gambar 10. Komparasi hubungan PGA dengan intensitas dari data BMKG dan USGS.

Nilai PGA pada suatu wilayah dipengaruhi oleh nilai intensitas gempa bumi. Semakin besar intensitasnya maka semakin besar juga nilai PGA sehingga terdapat suatu hubungan yang berbanding lurus antara nilai intensitas dengan nilai PGA. Hubungan PGA dengan intensitas pada Pers. (5) dari data BMKG dan USGS dapat dilihat pada Gambar 10. Grafik pada Gambar 10 menjadi bukti bahwa PGA dan intensitas memiliki hubungan berbanding lurus.

Nilai intensitas yang diakibatkan oleh gempa bumi akan semakin kecil seiring dengan bertambahnya jarak episenter gempa bumi. Sehingga menghasilkan hubungan yang berbanding terbalik antara nilai intensitas dengan jarak episenter. Hubungan intensitas maksimum dengan jarak episenter pada Pers. (6) menghasilkan grafik pada Gambar 11 dan menghasilkan persamaan exponensial $\mathrm{R}^{2}=0,996 \approx 1$ pada data $\mathrm{BMKG}$ dan $\mathrm{R}^{2}=0,993 \approx 1$ pada data USGS. Pada metode Gutenberg-Richter hubungan intensitas maksimum terhadap jarak episenter didapatkan dari fungsi atenuasi hubungan intensitas terhadap jarak menurut Subardjo dan Haryadi (1993) pada Pers. (6) akan menghasilkan garis kurva linier dengan $\mathrm{R}^{2}=0,997 \approx 1$, artinya metode Gutenberg- 
Richter memiliki ketepatan nilai dengan data sebenarnya. Namun jika dilihat dari hasil yang diperoleh terdapat sedikit perbedaan antara nilai dari BMKG dan USGS, ditunjukkan bahwa nilai fungsi atenuasi dari BMKG lebih mendekati 1 dibandingkan USGS. Hal ini disebabkan kemungkinan kesalahan pada pembulatan saat perhitungan.

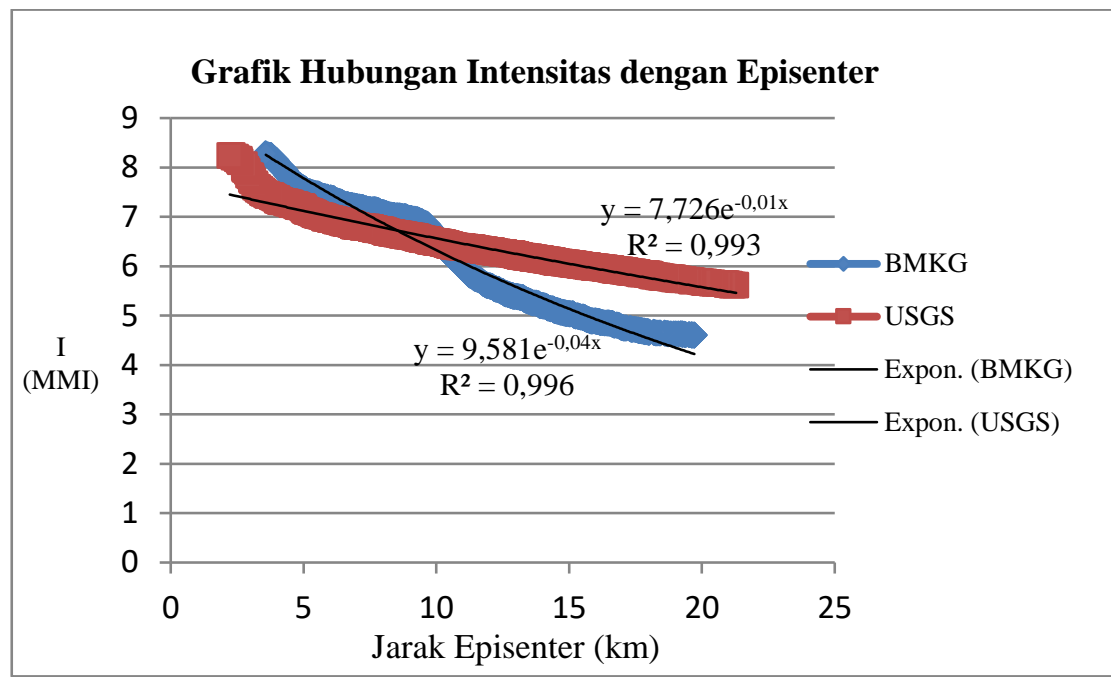

Gambar 11. Komparasi hubungan intensitas dengan jarak episenter.

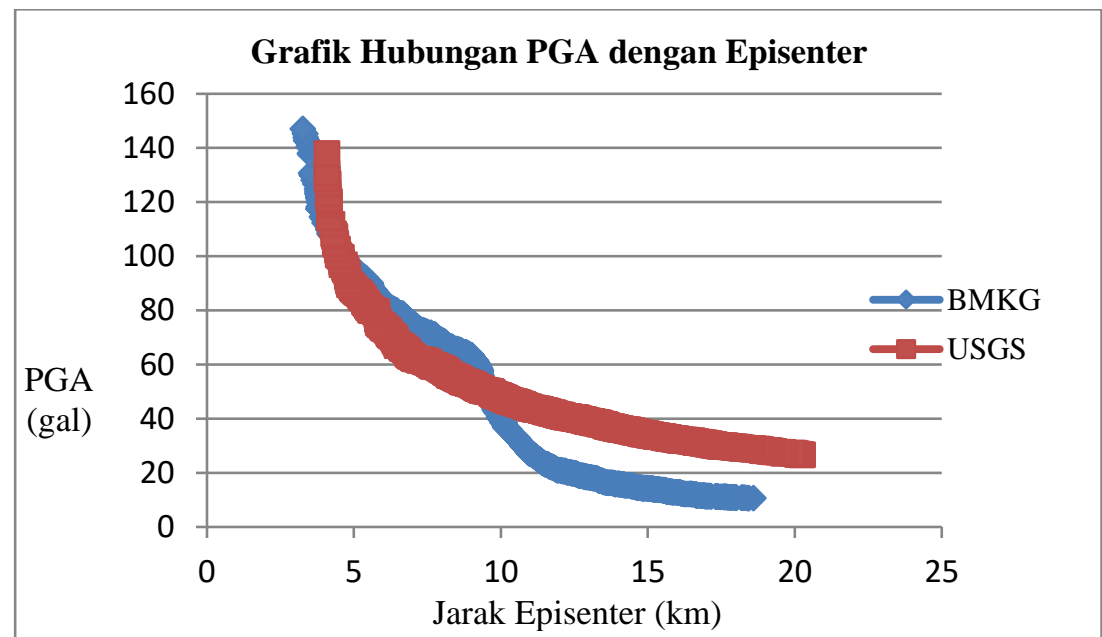

Gambar 12. Komparasi hubungan PGA dengan jarak episenter.

Nilai standar deviasi yang diperoleh menyatakan bahwa data dari BMKG lebih akurat dibandingkan dengan USGS. Karena pada metode Gutenberg-Richter $\mathrm{R}^{2}=1$ artinya hubungan jarak dengan intensitas untuk setiap jarak tertentu dapat dipastikan nilai intensitasnya. Selain itu, pada perhitungan nilai intensitas maksimum dengan metode Gutenberg-Richter, yaitu pada saat jarak tertentu dan bahkan hampir sangat berdekatan dengan episenter, nilai intensitas maksimumnya selalu di bawah nilai intensitas yang ada di episenter.
Pada grafik hubungan antara PGA dengan jarak episenter (Gambar 12) menggunakan Pers. (1) ditunjukkan bahwa data BMKG memiliki nilai percepatan lebih tinggi dibandingkan data USGS. Pada Gambar 11 ditunjukkan bahwa hubungan antara nilai PGA dengan jarak episenter adalah hubungan terbalik. Berdasarkan Gambar 11, nilai PGA dari USGS lebih stabil dibandingkan dengan nilai dari BMKG. Karena grafik menunjukkan bahwa penurunan nilai PGA dari USGS seiring dengan bertambahnya jarak episenter stabil. Sedangkan penurunan nilai PGA dari 
BMKG seiring dengan bertambahnya jarak episenter gempa bumi kurang stabil karena adanya penurunan yang signifikan pada jarak 9-10 km. Jadi, efek risiko yang diakibatkan oleh gempa bumi dari USGS lebih luas dibandingkan efek dari BMKG karena jarak episenter akan mempengaruhi risiko gempa yang ditimbulkan.

Interpretasi dilakukan setelah mendapatkan nilai percepatan tanah maksimum dan intensitas melalui perhitungan dan pemetaan. Berdasarkan Tabel 3, wilayah dengan tingkat risiko besar adalah Kabupaten Tanah Datar dan Kepulauan Mentawai. Wilayah Kabupaten Padang Pariaman dan Kota Pariaman memiliki tingkat risiko sedang dua. Tingkat risiko sedang satu dimiliki oleh Kota Padang Panjang, Kota Sawahlunto, Kota Padang, dan Kabupaten Pesisir Selatan, sedangkan wilayah lain memiliki tingkat risiko kecil.

Tabel 3. Tingkat risiko gempa dari data BMKG.

\begin{tabular}{clccc}
\hline No & \multicolumn{1}{c}{ Kota/Kabupaten } & MMI & PGA $\left(\mathrm{m} / \mathrm{s}^{2}\right)$ & Zona Bahaya \\
\hline 1 & Kab. Pasaman Barat & VI & 0,31 & Risiko kecil \\
2 & Kab. Pasaman & VI & 0,28 & Risiko kecil \\
3 & Kab. Lima Puluh Kota & VI & 0,45 & Risiko kecil \\
4 & Kota Payakumbuh & V & 0,16 & Risiko sangat kecil \\
5 & Kab. Agam & VI & 0,45 & Risiko kecil \\
6 & Kota Bukittinggi & VI & 0,38 & Risiko kecil \\
7 & Kota Padang Panjang & VII & 0,72 & Risiko sedang satu \\
8 & Kab. Tanah Datar & VIII & 1,44 & Risiko besar satu \\
9 & Kota Sawahlunto & VII & 0,69 & Risiko sedang satu \\
10 & Kab. Sijunjung & VI & 0,28 & Risiko kecil \\
11 & Kota Solok & VI & 0,31 & Risiko kecil \\
12 & Kab. Solok & VI & 0,46 & Risiko kecil \\
13 & Kab. Dharmasraya & VI & 0,32 & Risiko kecil \\
14 & Kab. Solok Selatan & VI & 0,33 & Risiko kecil \\
15 & Kab. Pesisir Selatan & VII & 0,68 & Risiko sedang satu \\
16 & Kota Padang & VII & 0,55 & Risiko sedang satu \\
17 & Kota Pariaman & VII & 0,89 & Risiko sedang dua \\
18 & Kab. Padang Pariaman & VII & 0,87 & Risiko sedang dua \\
19 & Kab. Kepulauan Mentawai & VIII & 1,43 & Risiko besar satu \\
\hline
\end{tabular}

Tabel 4. Tingkat risiko gempa dari data USGS.

\begin{tabular}{clccc}
\hline No & \multicolumn{1}{c}{ Kota/Kabupaten } & MMI & PGA $\left(\mathrm{m} / \mathrm{s}^{2}\right)$ & Zona Bahaya \\
\hline 1 & Kab. Pasaman Barat & VI & 0,32 & Risiko kecil \\
2 & Kab. Pasaman & VI & 0,28 & Risiko kecil \\
3 & Kab. Lima Puluh Kota & VI & 0,28 & Risiko kecil \\
4 & Kota Payakumbuh & VI & 0,28 & Risiko kecil \\
5 & Kab. Agam & VI & 0,28 & Risiko kecil \\
6 & Kota Bukittinggi & VI & 0,32 & Risiko kecil \\
7 & Kota Padang Panjang & VI & 0,39 & Risiko kecil \\
8 & Kab. Tanah Datar & VII & 0,51 & Risiko sedang satu \\
9 & Kota Sawahlunto & VI & 0,45 & Risiko kecil \\
10 & Kab. Sijunjung & VI & 0,29 & Risiko kecil \\
11 & Kab. Solok & VII & 0,87 & Risiko sedang satu \\
12 & Kota Solok & VI & 0,49 & Risiko kecil \\
13 & Kab. Dharmasraya & VI & 0,44 & Risiko kecil \\
14 & Kab. Solok Selatan & VII & 0,50 & Risiko sedang satu \\
15 & Kab. Pesisir Selatan & VIII & 1,35 & Risiko besar \\
16 & Kota Padang & VI & 0,49 & Risiko kecil \\
17 & Kota Pariaman & VI & 0,49 & Risiko kecil \\
18 & Kab. Padang Pariaman & VI & 0,37 & Risiko kecil \\
19 & Kab. Kepulauan Mentawai & VIII & 1,29 & Risiko besar satu \\
\hline
\end{tabular}


Berdasarkan Tabel 4, Kabupaten Pesisir Selatan dan Kepulauan Mentawai memiliki tingkat risiko besar satu dan paling tinggi di wilayah Sumatra Barat. Kabupaten Tanah Datar, Solok, dan Solok Selatan memiliki tingkat risiko sedang satu. Sedangkan wilayah lain memiliki tingkat risiko kecil.

Baik menurut data BMKG maupun USGS, wilayah di Sumatra Barat yang memiliki tingkat risiko tinggi adalah Kepulauan Mentawai. Hal ini dikarenakan Kepulauan Mentawai merupakan cekungan depan busur di antara zona akresi (tinggian depan busur) dan busur magmatik. Bahkan Kepulauan Mentawai adalah wilayah yang berpotensi tinggi mengalami tsunami. Tsunami bisa terjadi karena gempa tektonik, letusan gunung api, atau longsoran terjadi di dasar laut. Gempa yang menyebabkan tsunami memiliki ciri-ciri, yaitu lokasi episenter terletak di laut, kedalaman dangkal $(<70 \mathrm{~km})$, magnitudo M >7, mekanisme pensesarannya adalah sesar naik dan sesar turun (Lubis dkk., 2007).

\section{Kesimpulan}

Berdasarkan hasil dan analisis, nilai PGA menggunakan metode Gutenberg-Richter di wilayah Sumatra Barat dari BMKG yaitu $0,16-1,44 \mathrm{~m} / \mathrm{s}^{2}$ sedangkan dari USGS 0,28 $-1,35 \mathrm{~m} / \mathrm{s}^{2}$. Nilai intensitas dari BMKG sekitar V - VIII MMI sedangkan dari USGS sekitar VI - VIII MMI. Nilai PGA memiliki hubungan yang berbanding lurus dengan nilai intensitas gempa bumi. BMKG dan USGS memiliki perbedaan data dan hasil yang disebabkan faktor penentuan waktu tiba gelombang, distribusi stasiun, dan penggunaan model kecepatan.

Berdasarkan hubungan intensitas dan episenter dihasilkan nilai standar deviasi $\mathrm{R}^{2}$ $=0,996 \approx 1$ pada data $\mathrm{BMKG}$ dan $\mathrm{R}^{2}=$ $0,993 \approx 1$ pada data USGS. Pada metode Gutenberg-Richter hubungan intensitas maksimum terhadap jarak episenter menghasilkan garis kurva linier dengan $\mathrm{R}^{2}$
$=0,997 \approx 1$, artinya metode GutenbergRichter memiliki ketepatan nilai dengan data sebenarnya. Namun, dari pengolahan diperoleh nilai fungsi atenuasi dari BMKG lebih mendekati 1 dibandingkan USGS. Oleh karena itu, data dari BMKG lebih akurat dibandingkan dari USGS.

Wilayah Sumatra Barat dengan tingkat risiko besar satu berada di wilayah Kepulauan Mentawai dengan nilai PGA sekitar $1,29-1,44 \mathrm{~m} / \mathrm{s}^{2}$ dan intensitas sekitar VII - VIII MMI. Wilayah dengan tingkat risiko kecil berada di bagian Timur Sumatra Barat.

\section{Ucapan Terima Kasih}

Penulis mengucapkan terima kasih kepada BMKG dan USGS (AS) yang telah memberikan akses publik dalam penggunaan data katalog gempa bumi sebagai bahan penelitian. Terima kasih juga kepada Program Studi Teknik Geofisika Universitas Jambi karena telah menyediakan perangkat lunak untuk mengerjakan pengolahan dan analisis data.

\section{Daftar Pustaka}

Badan Informasi Geospasial (BIG). 2017. InaCORS BIG: Satu Referensi Pemetaan Indonesia. Pusat Jaring Kontrol Geodesi dan Geodinamika Badan Informasi Geospasial. https://srgi.big.go.id/download/info _produk/INFO\%20CORS.pdf

Bullen, K.E. 1965. Allowance for Seismic Velocity Gradient in a Horizontally Layered Flat Earth. Geophysical Journal of the Royal Astronomical Society. 10(1), pp.45-49. https://doi.org/10.1111/j.1365246X.1965.tb03049.x

BMKG. 2021. Monitoring Data Gempa Bumi Januari 2005 - September 2020. [Online]. [Accessed 21 January 2021]. Available from: http://www.dataonline.bmkg.go.id/Dat a Kejadian Gempa Bumi 
Calvi, G.M., Pinho, R., Magenes, G., Bommer, J.J., Restrepo-Vélez, L.F., dan Crowley, H. 2006. Development of Seismic Vulnerability Assessment Methodologies Over the Past 30 Years. ISET Journal of Earthquake Technology, Paper No. 472. 3, pp.75-104.

https://www.researchgate.net/publi cation/241826044_Development_o f_seismic vulnerability assessmen t_methodologies_over_the past_30 years

Douglas, J. 2001. Engineering Seismology and Earthquake Engineering. London: Imperical College of Science, Technology and Medicine, Civil Engineering Department.

Kawashumi, H. 1951. Measure of Earthquake Danger and Expectancy of Maximum Intensity Throughout Japan as Inferred from The Seismic Activity in Historical Times. Earthquake Res. Inst. Tokyo University.

Koesoemadinata, R.P. dan Matasak, Th. 1981. Stratigraphy and Sedimentation Ombilin Basin Central Sumatra (West Sumatera Province). Tenth Annual Convention IPA.

https://www.researchgate.net/publi cation/292282982_Stratigraphy_an d_sedimentation_Ombilin_Basin_ Central_Sumatra

Lubis, S., Hutagaol P.J., and Salahuddin M. 2007. Tectonic Setting in the Vicinity of Subduction Zone off West Sumatra and South Java. Proceeding APRU/AEARU Research Symposium 2007, Jakarta. Marlisa., Pujiastuti, D. dan Billyanto, R. 2016. Analisis Percepatan Tanah Maksimum Wilayah Sumatera Barat (Studi Kasus Gempa Bumi 8 Maret 1977 dan 11 September 2014). Jurnal Fisika Unand. 5(1). https://doi.org/10.25077/jfu.5.1.53$\underline{58.2016}$
Neumann, F. 1954. Earthquake Intensity and Related Ground Motion. Seattle: University of Washington Press.

Scordilis, E. 2006. Empirical Global Relations Converting $\mathrm{Ms}$ and $\mathrm{Mb}$ to Moment Magnitude. Journal of Seismology 10: pp. 225-236. DOI: https://doi.org/10.1007/s10950006-9012-4

Sieh, K. and Natawidjaja, D.H. 2000. Neotectonics of Sumatran Fault, Indonesia. Journal of Geophysical Research. 105(B12), pp.28.29528.326.

https://doi.org/10/1029/2000JB900 $\underline{120}$

Subardjo., dan Haryadi, P.J. 1993. Fungsi Atenuasi Intensitas Gempa Flores 12 Desember 1992. Proceding PITHAGI.

Syahputra, H. 2007. Perhitungan Percepatan Getaran Tanah Maksimum di Wilayah Aceh dan Kepulauan Andaman Nicobar (India) Menggunakan Metode McGuirre. Skripsi. Program Studi Geofisika UGM, Yogyakarta.

USGS. 2021. Search Earthquake Catalog. [Online]. [Accessed 25 January 2021]. Available from: http://www.earthquake.usgs.gov/ea rthquakes/search 